\title{
Hepatitis C in prisons
}

\author{
Alavian SM (1)
}

(1) Baqiyatallah Research Center for Gastroenterology and Liver Disease (BRCGL), Baqiyatallah University of Medical Sciences, Tehran, Iran.

\section{Dear Sir,}

I read the article by Pompilio et al. (1) in your journal. Indeed, incarceration is a major risk factor for blood-borne infection among intravenous drug users (IDUs) $(2,3)$. Most cases of hepatitis $\mathrm{C}$ virus (HCV) infection are asymptomatic and undoubtedly finding the key routes of transmission, particularly in endemic regions, is a priority. The importance of programs that aim at controlling risk factors becomes clearer when many infected patients with hepatitis appear asymptomatic (4). Currently, approximately 170 million people are infected with $\operatorname{HCV}(2,5)$. Injecting drug use is the most common route of transmission, thus IDUs have the highest prevalence of HCV infection and also constitute a potential reservoir of $\mathrm{HCV}$ in the community (6-8).

The lower prevalence of $\mathrm{HCV}$ infection in prison population in the study by Pompilio et al. (1) in comparison with previous Brazilian works may be related to improvement in access to educational materials and harm reduction programs $(1,9)$. Harm reduction is the core activity for controlling risky behaviors - such as sharing syringes - among infected persons whereas noninfected ones may be offered other supportive services to prevent the spread of HCV and HIV. We hope that the already-in-place program of harm reduction gets national exposure, so that to cover all high-risk populations including IDUs in and out of prison.
IDUs are at higher risk of acquiring $\mathrm{HCV}$ infection especially when they enter the prison and share needles (10). Variables that are identified as independent predictors of $\mathrm{HCV}$ infection include duration of injecting, frequency of injecting, needle-sharing, and prior imprisonment (11). Besides sharing needles, sharing balls of cotton wool may be a source of HCV infection (12). Other contributory factors for HCV transmission are needle stick injuries, contaminated medical equipment, and blood spills in health care settings $(13,14)$.

It is also worth mentioning blood transfusion history in prisoners particularly due to surgeries, which is significantly more common in HCV positive group, as a risk factor for contamination (1, 15). Similarly, hospital admission, experimental dental treatment and extramarital sexual contact should be considered risk factors for HCV transmission (15). Finally, I would like to mention that HCV will be more important in the future as a major cause of liver disease-related morbidity and mortality worldwide and will represent a major public health problem. If we are more careful today, the future will be safer for our community.

\section{COPYRIGHT \\ (c) CEVAP 2011}

\section{SUBMISSION STATUS}

Received: June 10, 2011.

Accepted: June 10, 2011. 
Full paper published online: August 31, 2011.

\section{CONFLICTS OF INTEREST}

There is no conflict.

\section{CORRESPONDENCE TO}

SEYED-MOAYED ALAVIAN, Department of Internal Medicine, Gastroenterology and Hepatology, Baqiyatallah Research Center for Gastroenterology and Liver Disease, Vanaq Square, Mola Sadra St., Tehran, PO box 141553651, Iran. Telephone: +98 2188945186. Fax: +98 2188945188. Email: alavian@thc.ir.

\section{REFERENCES}

1. Pompilio MA, Pontes ERJC, Castro ARCM, Andrade SMO, Stief ACF, Martins RMB, et al. Prevalence and epidemiology of chronic hepatitis C among prisoners of Mato Grosso do Sul State, Brazil. J Venom Anim Toxins incl Trop Dis. 2011;17(2):216-22.

2. Mir-Nasseri MM, Mohammadkhani A, Tavakkoli H, Ansari E, Poustchi H. Incarceration is a major risk factor for blood-borne infection among intravenous drug users. Hepat Mon. 2011;11(1):19-22.

3. Fallahian F, Najafi A, Alavian SM. Intravenous drug use: the predominant risk factors for hepatitis C virus infection. Shiraz E-Med J. 2010;11(4):209-18.

4. Alavian SM. Control of hepatitis $\mathrm{C}$ in Iran: vision and missions. Hepat Mon. 2007;7(2):57-8.

5. Pham ST, Bull RA, Bennett JM, Rawlinson WD, Dore GJ, Lloyd AR, et al. Frequent multiple hepatitis $\mathrm{C}$ virus infections among injection drug users in a prison setting. Hepatology. 2010;52(5):1564-72.

6. Joukar F, Besharati S, Mirpour H, MansourGhanaei F. Hepatitis C and hepatitis B seroprevalence and associated risk factors in hemodialysis patients in Guilan province, north of Iran. Hepat Mon. 2011;11(3):178-81.
7. Amini Kafiabad M, Samiei S, Talebian A, Maghsudloo M, Gharehbaghian A. Hepatitis G virus infection in Iranian blood donors and highrisk groups. Hepat Mon. 2009;9(4):282-6.

8. Alavian SM, Tabatabaei SV, Lankarani KB. Epidemiology of HCV infection among thalassemia patients in eastern Mediterranean countries: a quantitative review of literature. Iran Red Cres Med J. 2010;12(4):365-76.

9. Azarkar Z, Sharifzadeh G. Evaluation of the prevalence of hepatitis $B$, hepatitis $C$, and HIV in inmates with drug-related convictions in Birjand, Iran in 2008. Hepat Mon. 2010;10(1):26-30.

10. Luksamijarulkul P, Triamchaisri S. Relationship between antibodies to hepatitis $\mathrm{C}$ virus and human immunodeficiency virus among Thai selected groups. Hepat Mon. 2009;9(1):66-9.

11. Aitken CK, Lewis J, Hocking J, Bowden D, Hellard M. Does information about IDUs' injecting networks predict exposure to the hepatitis C virus? Hepat Mon. 2009;9(1):17-23.

12. Mboto CI, Takon IA, Ndem JE. A used ball of cotton wool as a source of nosocomially-acquired hepatitis C infection. Hepat Mon. 2010;10(1):536.

13. Lu H. Intrafamily transmission of $\mathrm{HCV}$ need to more discussion. Iran Red Cres Med J. 2011;13(2):141.

14. Ataei B, Tayeri K, Kassaeian N, Farajzadegan $\mathrm{Z}$, Babak A. Hepatitis B and C among patients infected with human immunodeficiency virus in Isfahan, Iran: seroprevalence and associated factors. Hepat Mon. 2010;10(3):188-92.

15. Alavian SM, Gholami B, Masarrat S. Hepatitis C risk factors in Iranian volunteer blood donors: A case-control study. J Gastroenterol Hepatol. 2002;17(10):1092-7. 